\title{
Sound, Vision, and Representation: Pageantry in 1610 Chester.
}

This article examines a civic entertainment staged in Chester in 1610. It explores how visual, verbal, and aural elements of the event contributed to its construction of popular and elite responses, revealing complex circuits of representation. Multiple elements of identity overlap in the show's portrayal of Chester's place in Jacobean Britain. A discussion of different textual forms, contexts, musical resources, constructions of authorship, and evidence of reception associated with the event elucidates this portrayal. We must examine the non-verbal elements, especially music, alongside the verbal elements of occasional drama, if we are to fully recognize the complexity of their strategies of representation.

Chesters Triumph in Honor of Her Prince is a printed description of festivities staged on St George's Day, 1610, in Chester. As well as various theatrical elements this occasion saw the inauguration of the St George's Day races, which continue to this day. The prince in question was Henry Frederick, son and heir of James VI and I, whose creation as prince of Wales on 4 June 1610 would also see him assume several other titles traditional to the eldest son of the English monarch, including the earldom of Chester. ${ }^{1}$ In the very broadest sense, then, Henry might be seen as the event's 'author', in that he could be considered its 'first cause'. Certainly the prince would seem, at first glance at this text, to be the primary 'audience' and/or 'reader'. Although some aspects of the pageantry and its commemorative text (most noticeably the title) present themselves as directly addressing Prince Henry, others are clearly more concerned with different, more local audiences. We have no evidence that Henry was present at this event and closer inspection reveals that he is no more meaningful an audience to either event or text than St George, who

Susan Anderson (s.anderson@leedstrinity.ac.uk) is senior lecturer in the department of English at Leeds Trinity University. 
was also 'addressed'. Like St George, Henry is a phantom audience, a cipher that creates space for signification and representation in text and event.

This curious absent presence has attracted the attention of several critics, most notably David M. Bergeron, who has discussed Chesters Triumph on a number of occasions. ${ }^{2} \mathrm{His}$ most recent discussion of the triumph reiterates his approach, asserting that its 'dramatic center' is 'the ageless struggle between virtue and vice; the victory of the virtuous forces cleanses the city and creates a new harmonious place for the prince, possibly a new St George.. ${ }^{3}$ The confrontation between Envie and Love that this statement refers to is indeed one of the more notable elements of the text, but Bergeron's concentration on finding thematic unity in the pageantry ignores the fault-lines that the text and event seek to smooth over. Robert W. Barrett, by contrast, argues that the allegorical figure of Envie in the performance corresponds to conflict within contemporary local politics. ${ }^{4}$ Barrett shows that the triumph's emphasis on a coherent Cestrian identity exposes the way that competing interest groups claim such an identity.

Neither of these critics, however, considers the musical elements of the performance. David Mills takes a slightly more interdisciplinary view of the event, likening its 'pot-pourri of different components' to the Cestrian midsummer shows of the sixteenth century. ${ }^{5}$ Nevertheless, Mills does not discuss the aural properties of Chesters Triumph in any detail. ${ }^{6}$ This kind of omission is a consistent feature of criticism of occasional and courtly entertainments more generally. ${ }^{7}$ Yet music was an indispensable element of all forms of pageantry. The shows most usually featured drums and trumpets, but many other forms of instrumental and vocal music, as well as noise such as the shooting of artillery, also contributed to the aural experience of pageantry. ${ }^{8}$

The reasons for critical inattention to the soundscapes of pageantry are not hard to see. The texts that survive place far more emphasis on the visual and verbal elements that they describe and transcribe than on music.? Indeed, music is almost never transcribed in these contexts - and understandably so, since musical culture was still overwhelmingly based on learning by ear. ${ }^{10}$ Nevertheless, usable evidence regarding the musical elements of performances does exist, both circumstantially in documents such as payment records, and in the way that commemorative texts themselves construct music and its meanings. Music read through descriptions and song lyrics can yield insights not just about performance practice, but also about the political and symbolic resonances of an event. Music, therefore, is not 
just interesting in its own right, but can refine our understanding of the politics of representation in early modern occasional entertainments.

The two extant descriptions of the event make it apparent that plenty of music was on offer at Chester in 1610. The first is a manuscript that forms a plan of the event, rather than a descriptive account. It seems to be a proposal by a Chester citizen, Robert Amery, for an event to celebrate St George's Day (the prince's investiture is not mentioned). The document comprises a list of acts to be included in a display and procession, including horseracing with concomitant prizes and prize-giving, and is written in the future tense. ${ }^{11}$ The second description is the printed version entitled Chesters Triumph in Honor of her Prince, produced later in 1610 to memorialize the event. It, too, features a list of the entertainment's elements and incorporates extensive additions, including a dedicatory poem to Prince Henry, an address to the reader, and the speeches delivered at the event. ${ }^{12}$

According to this document, the entertainment opened with an unnamed man climbing to the top of St Peter's steeple and performing a handstand upon the iron bar at the top. As well as attracting attention by sounding a drum and shooting a piece, the performer unfurled a banner of St George's colours and flourished a sword - a clear indication of the incipient militarism of this chivalric mythology, ${ }^{13}$ and possibly connected to the hopes for more aggressive foreign and religious policies that clustered around Prince Henry. 14

Subsequent musical elements echoed this militaristic opening. In addition to the drum the steeple-climber played, 'a noyse of Drummes' accompanied St George, 'many Trumpets sounding cheerefully' before the horseman carrying the arms of the king in the procession, and a 'noyse of Cornets' before the arms of the prince. ${ }^{15}$ The personation of Chester also requires drums. Interestingly, the manuscript twice specifies music to be part of Mercury's entrance to the entertainment. Clearly the organizer had something in mind when he stipulated 'heavenly Musick'. ${ }^{16}$ Perhaps 'heavenly' referred to the placing of the musicians high up in the steeple, but equally, it might indicate something of the intended style of the music. According to JoAnna Dutka, the music of the heavenly in mystery plays (ie the appearance of angels or God) was very similar to, or borrowed from, the polyphonic music of parts of the liturgy. ${ }^{17}$ The 'song of eight voyces' (B2v) which introduces Mercury could have imitated this music in some way.

The last performance of the mystery plays in Chester was in 1575, however, and musical fashions had changed in the intervening decades. ${ }^{18} \mathrm{~A}$ 
song of eight voices in the early-seventeenth-century context would more likely have been a motet, ${ }^{19}$ or a madrigal or something approaching its style. Eight would have been an extremely unusual number of parts, but perhaps the number refers to the number of singers, implying a doubling up. Francis Pilkington, a singing man of Chester cathedral, published two books of madrigals, in 1614 and 1624, and it is tempting to suggest that he could have provided such music. ${ }^{20} 1610$ is rather late in the short history of the madrigal, according to Jerome Roche, but Pilkington's belatedness in this respect might indicate that the genre still had some currency. ${ }^{21}$ The complexity suggested by eight voices indicates that this song was a distinctive part of the show's soundscape. The moment it showcases was, as I argue below, a more significant element than prior critics have recognized, concentrating as they do on the verbal jousting between Love and Envie.

The payments for the 1610 triumph do not name any musicians, but as the work of David Mills has shown, Chester was particularly well-supplied with musicians who may have been able to contribute to festivities in this period. ${ }^{22}$ In addition to any cathedral singers who might have been involved, the brothers Robert and George Kelly (or Calley, or various other spellings) almost certainly participated, leading a secular corps of Chester musicians. There are payments for music on all sorts of public occasions, including events similar to the St George's Day show and races in 1610, to one or other of the brothers (initially both, often listed as 'the kellyes') from the end of the sixteenth century to halfway through the seventeenth. ${ }^{23}$ Neither of the brothers joined the town waits until at least 1613, but they appear to have been well established even before this time. ${ }^{24}$

A drummer named Roger Guest or Gest could conceivably have been employed at the 1610 show. He was first paid twelve pence for drumming on Shrove Tuesday in 1612, and he is the only named drummer in the Chester records. He seems to have regularly provided his services for public events until the last mention of him in 1641. His name first appears in connection with the St George's Day races in 1615. ${ }^{25}$ It could be that he was first brought in to drum for the 1610 event.

Other musicians who may have participated in the 1610 entertainment include the four 'strangers' George Kelly railed against in a 1615 petition aimed at preventing them from stealing his business. This appeal included the 'arte of dauncinge \& the teachinge therof' as well as 'the science of musicke. ${ }^{26}$ One of Kelly's targets, Thomas Squier, may well have been the same person as the 'Squire' who in November 1613 received eighteen pence 
for playing 'on the cornett upon the kinges day' and then a further six shillings and eightpence 'by mr Mayors appoyntment to gett him out of the Cittye'. ${ }^{27}$

Cheshire had a unique exemption from the 1572 Statute of Vagabonds, allowing the local Dutton family to register unliveried musicians. They were then protected from the punishments for vagabondage in the same way that the liveried servants of the nobility were. ${ }^{28}$ This process, as Baldwin points out, evolved into what was essentially a form of taxation on the local minstrels, who had to pay $4 \mathrm{~d}$ annually for their licences. ${ }^{29}$

The presence of the licensed minstrels and the Kelly brothers' careers both show that the general level of opportunity for earning through music was fairly high in Chester. The opportunity was not unlimited, however, as George Kelly's petition shows, and the constraints could also explain various altercations between musicians that the archives record, including a dispute between the Kellys themselves. ${ }^{30}$ Nevertheless, a thriving musical culture in the city meant that Chesters Triumph had a sizeable pool of musicians to draw upon to provide musical as well as visual and verbal signification.

A telling difference between the manuscript and printed documents with regard to instrumentation indicates music's iconographic significance at the event. The manuscript stipulates that a 'noise of trumpettes' should be carried before the prince's and the king's coats of arms in the procession. ${ }^{31}$ In the printed account, these instructions change. Whilst the king's arms retain their guard of trumpets, a 'noyse of Cornets' precedes the prince's arms (A4r). This change could merely reflect a shortage of trumpeters to supply the demands of the procession, but this scarcity seems unlikely considering the evidence of musical personnel noted above. Instead, the alteration appears to reinforce the relative statuses which the procession's representations of the royal personages denote. Trumpets were an instrument of ancient origin whose ceremonial use in peace and war had given them a venerable status as fitting instruments to herald a king. Cornetts (a wind instrument - not the modern trumpet-like cornet) had an entirely different provenance, however, and were mainly associated with hunting. ${ }^{32}$ As Barrett notes, the coats of arms on display in the procession were visual symbols of absent royal bodies, and offer 'the virtual presence of the royal figures their devices represent' through a kind of metonymic association. ${ }^{33}$ The music of the pageant also participates, therefore, in the discourse of the symbols of aristocratic hierarchy. It subtly reinforces the king's place above the prince's and helps to endow the symbolic representations of aristocracy — the coats 
of arms - with the significance needed first to justify the procession's own existence, but also to appropriate part of that authority and kudos for the procession itself.

As Barrett notes, and as the distribution of musical resources reflects, the different kinds of audience at this event, present and imagined, are strictly hierarchized. Both texts explicitly lay out the order of the parade of arms and escutcheons to determine and preserve its hierarchical sequence. The order of the speeches made at the crossroads in the city also provides an indication of the event's political priorities. After Mercury's opening address came Chester's speech, then the speeches of Britain and then Cambria, who praised King James and Prince Henry respectively, replicating the order in which their coats of arms were carried. An oration to Saint George followed this procession, and then 'Peace' and 'Plenty' gave speeches. The sequence thus started locally and specifically, and progressively became more abstract, placing the here and now before remoter authorities and ideals.

Indeed, Chester's speech focused on local hierarchies, as she specifically welcomed the town's elite to the pageant, invoking 'sage Spectators' described as a 'blisfull criew, / Whose light lends luster to the vulgar view' (B3v). The spectators she addresses here were also participating in the event itself. As the printed description reveals, 'The Mayor, Sheriffs and Aldermen of Chester, arayed in their Scarlet, having seene the said shewes, to grace the same, accompanied, and followed the Actors unto the said Roode' (A4v-B1r). The town dignitaries form part of the spectacle, taking their places in the procession to the racecourse, their robes of office marking them out as objects of display concurrently with their observation of the event. Chester's assertion that the 'light' of the elite 'lends luster to the vulgar view' claims that these viewers illuminate each other and their surroundings, and both see and are seen by themselves and the rest of the spectators.

Chester's speech, furthermore, constructs a heroic role for these public servants by claiming

The Romaine Curtius Romes great Favorite,

(Whose daring Death did her from scathe acquite)

Was ne're more Welcome to the Romanes sights,

Then are your selves, to these our choise delights.

The story of Curtius, taken from Livy, serves as a kind of model for audience commitment and community participation. ${ }^{34}$ Marcus Curtius, a young soldier, supposedly threw himself as a sacrifice into a chasm that had opened 
in the midst of the Forum in Rome. His action caused the gulf to seal over and thus saved the city. Chester's reference draws together spectator and performer, eliding the distinctions between place and person as well as participant and viewer. The performers are the Roman viewers of Curtius's sacrifice, whilst the elite citizens are aligned with the figure who acts and who (literally) becomes part of his city. The speech reverses the personification of Chester, constructing the elite constituency of the audience as embodying the city, whilst the pageant actors look on.

Thus, the pageant presents an elite group of spectators as truly 'representing' the city, as individuals who stand in for the larger group. Just as a king's corporeal body can stand in for the body politic, and his coat of arms can in turn stand in for that corporeal body, the corporate body of Chester's governing assembly synechdochically stands in for the rest of the city. The show consolidates this representativeness by testing it against its opposite in the psychomachia between Love and Envie that Bergeron identifies as the essence of the pageant.

The figure of Envie provides an example of how not to respond to pageantry through her wilful misinterpretation of its good intent. The printed text describes Envie apparently inveigling her way into the procession and mocking the event, referring to it as 'a ranke of rustick Boyes / Shewing as childish people childish toyes / To grace a day with' (C3v). She declares that, rather than the fantastical scenes of pageant myth, she would prefer to see various unpleasant sights, including 'a City burnt, or Barnes on fire', or even 'an Army (when their foode is scant) / Eate their owne excrements' $(\mathrm{C} 3 \mathrm{v})$. Envie is a defective audience member, taking delight only in negativity. Her railing solicits approval for the event ironically by deprecating it and thus working to position the audience on the side of the organizers. When she wishes, for example, that 'Confusion, death, plague, pestilence, and piles, I Confound their soules who at mine anguish smiles' (C4r), the bathos of 'piles' being the last of her curses ${ }^{35}$ and the source of the rhyme seems likely to produce the smiles that read as approval of the banishment of Envie (and hence agreement that any opposition to the pageant is envious). ${ }^{36}$

Barrett is surely right in suggesting that Envie's presence in the show testifies to the competitive struggles for power and prestige within and on the edges of Chester's oligarchy. ${ }^{37}$ But other constituencies are here too. Although the pageant text insists upon differentiating between the 'nicer appetites' of the elite and the 'vulgar view' of the common people, this distinction should not lead us to ignore the non-elite elements of the audience. 
First, their presence is necessary in order for there to be a multitude against which to define a smaller, privileged selection. Second, their status as an undifferentiated group does not exclude them from the economies of representativeness that the event and text invoke, not least because they embody 'the people' of Chester and its environs, whom selected individuals represent in the triumph. Finally, the success of the event was partly predicated upon soliciting the approval of this population of spectators.

Popular approval was needed if the event was indeed to 'continue perpetually' (as the text's address to the reader predicts), because sufficient demand was required for it to keep going as an annual concern. A further petition to the mayor and aldermen in which Robert Amery requested 'a perpetuall establishment of a yearlie horsse race $\&$ runing at the ringe at the roode eye upon St George his day', reminding them that 'lately to this Peticioners greate trouble \& Charges' he did 'procure three Bell Cupps of silver to be made, with other shewes and devyses ... to this Peticioners Charge the some of C li. at the leaste', shows that perpetuity was the intention. ${ }^{38}$ The spectacle of horse racing is hardly complete without sufficient cheering spectators, and Amery's plans needed popular support as well as official sanction and financial aid.

Characterizing the unidentified, non-elite spectators who attended Chesters Triumph is difficult, partly because they were potentially so widely heterogeneous. Recent work on the composition of theatre audiences in London may yield some analogous information. Andrew Gurr follows the fourfold categorization from Harrison's The Description of England, dividing society into nobles/gentry, citizens/burgesses, yeomen, and artisans/ labourers, noting that such a taxonomy renders women's presence invisible. ${ }^{39}$ Alfred Harbage similarly reminds his readers that women formed a majority of the lower strata of society. ${ }^{40}$ Using muster rolls, he concludes that by far the most common occupation amongst working people was that of 'craftsman', accounting for those who made their living as, for example, 'carpenters, masons, bookbinders, and button makers. ${ }^{41}$ Gurr, Harbage, and Anne Jennalie Cook, but especially the latter, emphasize the importance of the admission fee in shaping the Shakespearean audience's composition, and the shortage of leisure time in most working people's lives, as severely limiting factors on their attendance at theatrical performances. ${ }^{42}$ On St George's Day 1610 in Chester, the occasion was more like a midsummer show than a closed theatrical performance. Rather than restricting the audience to a particular 
venue, the triumph appropriated the quotidian space of the city that was explicitly open to all, regardless of means or station.

Jeremy Lopez issues an important proviso in this respect, warning that some scholarship can give 'the impression of more rigidly segregated audiences and more easily dichotomized audience tastes than the evidence actually yields up. ${ }^{43}$ Specifically localized readings of performance, furthermore, can only make use of comparisons to the London theatre in very general terms. Clearly certain kinds of people were likely to be among the spectators of Chesters Triumph, but the text itself is unclear over which particular aspects of their identity were necessarily relevant at any given moment. Chesters Triumph does seek at various points to segregate its audience, yet it does not do so coherently or consistently. Representativeness, whether of social class, occupation, locality, or nationality, is fluid in the show, applied across and within different groups at different points. The text's verdict that 'none but fooles dispraised it' (A2v), for instance, distinguishes between spectators not by social status, but by discernment.

We need to read the show's construction of its audience within a specifically local context, as Barrett's discussion of oligarchic politics demonstrates. ${ }^{44}$ The history of Chester provides some indication of the factors that may have been pertinent to the show's representations. Although Chester's political and strategic importance was nowhere near what it had been during its medieval heyday, it was certainly still a regional centre. ${ }^{45}$ In 1610 Chester was undergoing the fastest rate of population growth it had ever experienced, after a severe outbreak of plague in 1603-5. Following the loss of around two thousand people, immigration restored population numbers amongst labourers and skilled craftspeople here, as in other similar towns. ${ }^{46}$ The 'strangers' that George Kelly so resented were, therefore, crucial to the city's recovery and chances of prosperity. Whether we see such people as 'representative' of Chester depends upon the context. In terms of the general population, A.D.M. Phillips and C.B. Phillips suggest that, in the sixteenth and seventeenth centuries, apprentices and domestic servants in the city were recruited from within a sixteen- to seventeen-mile radius. ${ }^{47}$ Traffic passed through on the way to and from Wales and Ireland as well as other parts of northern England. ${ }^{48}$ Events such as the Shrovetide races and the midsummer pageants had established Chester as a familiar destination for those seeking pageantry, sports, and festivity. ${ }^{49}$ The potential audience for the show was thus broad indeed. 
If nothing else, Chesters Triumph had a lot to live up to if it was to provide a genuinely popular entertainment that could find a place in the city's post-Reformation festive calendar. Amery's project does seem to have had some limited staying power, even after his death in 1612. Over the following decades, payments towards both the St George's Day races and the Shrove Tuesday races continued to appear in guild account books. Until 1623 the St George's race winners received the bells from the original 1610 event as trophies to keep for the year until the next race (as well as a portion of the entry fees). Eventually, the St George's Day meeting seems to have gradually replaced the Shrove Tuesday races altogether. ${ }^{50}$

The need to appeal to a popular audience does not appear to preclude the event's snobbish rhetoric of flattery, however, whereby speakers repeatedly differentiate between an elite, knowledgeable audience (with their 'nicer appetites' [B3v]) and a 'vulgar' one. The characters of both Love and Envie, for instance, make a point of talking directly to 'the best' elements of the audience (C4r-v), and at the end of the day's events, Chester gives a final speech publicly inviting 'Each noble worthy, and each worthy Knight / To close their stomacke with a small repast' (D1v). This address accords with the specification in the manuscript that there will be 'a banket after in the Pentis to make welcome the genntlemen'. ${ }^{51}$

Mercury's appearance at the beginning of the event invokes and dissolves such social differentiations. Mercury's oration differentiates and particularizes spectators, but the song accompanying his approach (noted above) uses music to encourage and represent a 'harmonious' social unification of all audience members. Accompanied by fireworks and 'with most pleasant and mellodious harmonie at his approach' (A3v), Mercury apparently descended from the steeple in a cloud, with Fame introducing him as a messenger from the gods, sent to 'salute your Governour' (B2r). Initially, and especially in light of the printed text's title and the display of the prince's blazon (A1v), this tribute may seem to be a reference to Henry and his imminent investiture, just as in many court masques the royal figure is the singular focal point of the entertainment who justifies the fictional proceedings. ${ }^{52}$ Mercury's oration directly addresses and praises the object of his speech, declaring 'All haile to thee high Justice Officer' (B3r), but, as noted above, Prince Henry was not present at this event. ${ }^{53}$ Barrett ultimately concludes, as I do, that it is 'more likely than not' that William Leicester, Chester's mayor, is 'the recipient of Mercury's gesture of acknowledgment'. ${ }^{54}$ According to the pageant, Leicester's 'fame on earth hath pierc'd the skie' (B3r), leading the gods to 
send Mercury to present 'a Favour favourably sent / From them, by me, to thee' (B3r). The figure of Mercury, the messenger of the gods, appropriately establishes the transparent connection between sign and signifier (Leicester's 'fame' is apparent and unmistakeable).

Mercury seems to be very specific here about who is speaking to whom, but as noted above, this identification is actually a matter of interpretation. Ultimately, the open-endedness of signification here represents a generic tactic of seventeenth-century occasional drama. For example, as Martin Butler points out, the nature of address in the court masque is ostensibly specific to the king, but in actuality encompasses further participants and addressees. As Butler remarks,

the spectators ..., though silent in the texts, had their own distinctive investments in the occasion. Typically the king was the principal addressee, but the nature of the encounters that masques performed depended on who was dancing, who was paying, and whether the show was simple homage and celebration or an act of supplication, persuasion, or rapprochement..$^{55}$

In one of his contributions to London's civic pageantry, Thomas Middleton noted how the spectacle of a lord mayor's show was intended to present pragmatic examples of good works that 'ought indeed to be the imitation of the beholder' (ll 187-8). ${ }^{56}$ The singular 'beholder' simultaneously particularizes and universalizes the imagined addressee of the show. ${ }^{57}$ The address Mercury directs in Chester operates in a similar way, with the mayor as a synecdoche of overlapping groups, such as other aldermen, or other citizens, who make up different audiences.

The music accompanying Mercury established yet further circuits of representation and response. The printed text preserves the lyrics for the 'song of eight voyces' that was performed during Mercury's entrance. They describe Mercury as the bringer of light, lustre, and vivification:

Come downe thou mighty messenger of blisse,

Come: we implore thee,

Let not thy glory be obscur' $\mathrm{d}$ from us

Who most adore thee:

Then come, $\mathrm{O}$ come great spirit

That we may joyfull sing, 


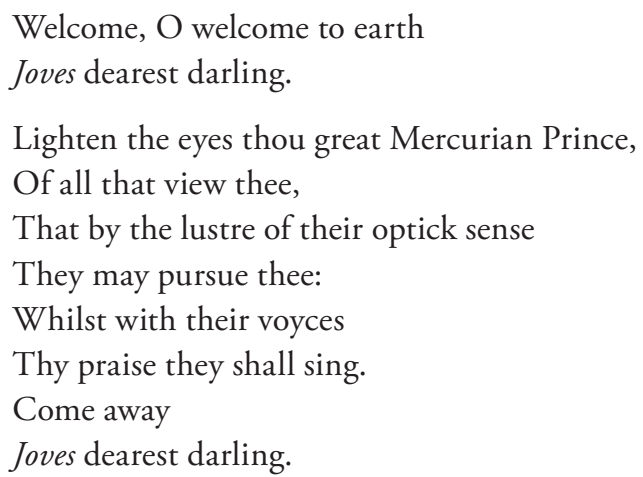

The song explicitly refers to the action with which it is simultaneous. In the first stanza, this movement is the lowering of Mercury from the steeple and his arrival on the ground. In the second, it is the pyrotechnical effects that indeed 'lightened' the spectators' eyes, and the sound of the song itself as it accompanied Mercury's descent. The performance thus enacts the song's description, creating an illusion of neoplatonic efficacy. ${ }^{58}$

The second stanza of the song illuminates the respective roles of hearing, sight, and sound in Jacobean pageantry. Rulers or privileged individuals (in this case, Mercury) are the focus of visual attention. The text usually describes observers, by contrast, in aural terms, most often in reference to the noise made by the crowds. ${ }^{59}$ As in the Chester song, pageantry portrays spectators as heard and not seen, participating by making joyful noise in praise of what they see.

The Chester lyrics analogize the cheers of the crowd with song, making music the proper response to this type of visual stimulus. In the first stanza, the singers refer to themselves in the first person plural, requesting that Mercury arrive so 'that we may joyfull sing'. In the second stanza, this pronoun converts into the third person plural of 'with their voyces / Thy praise they shall sing'. At first, the singers sing on behalf of the spectators, imploring Mercury to appear, but in the second stanza they project a response outwards, ventriloquizing the crowd's assumed approval. The text uses song to tell observers what they should be thinking, and to enact the appropriate response on their behalf.

Musical tropes continue to present a positive model for the response of spectators later in the show. When Love ejects Envie from the procession and publicly shames her, music is the emblem of the hegemony that results. This representation is clear when Joy declares 'avaunt; that all the I'le may 
sing, / Now Envies gone, in peace w'enjoy our King' (C4v). The obliterating sound of a universal music of sincerity assuages any fears of a mocking lack of respect. The show asserts that this sound signifies true agreement within hearts and minds as well as in outward appearance, reminding onlookers of what they (should) think and demanding their active participation in believing it. Potentially heterogeneous meanings, not just of the show itself, but also of the audiences' responses to it are thus homogenized as transparently evident musical signification.

That music is particularly appropriate for such a task is also apparent from its status as an emblem of harmony per se. As Gretchen Ludke Finney points out, musical harmony can both emphasize the importance of each separate element to the balance of the whole, whilst simultaneously insisting that each remains in its allotted place in a spatially-configured hierarchy. ${ }^{60}$ Music, therefore, is able to encompass both an atomized audience, divided into social groupings, and a homogenized city identity, subsumed into ever larger political and national entities. This universalizing impulse carries the purview of the pageant beyond Chester itself to 'all the I'le'. As Barrett argues, the publication of Chesters Triumph in London is a gesture of feudally-inflected homage that emphasizes 'Cestrian exceptionalism'. ${ }^{61}$ But beyond this emphasis, the text also asserts Chester as representative of a greater whole. The pageant implicitly presents the city, situated as it was on important routes between England, Wales, and Ireland, as more representative of national identity than London could ever be.

The description of the city elite as 'yonger Brutes' (B3v) situates Chester as a participant in national history by comparing the civic dignitaries to Brut, the mythical founder of Britain. The antiquity of a unified Britain was a popular myth drawn on by Jacobean pageant writers seeking to redefine nationhood in the light of the unification of the crowns of England and Scotland on James's accession to the English throne. ${ }^{62}$ Despite the failure of the king's attempts to establish a union of kingdoms, its rhetoric remained embedded in contemporary pageantry, which continued to eulogize his role in bringing the kingdoms together under his person. ${ }^{63}$

The Chester perspective on the politics of unification firmly places England as the dominant partner. The character of Peace, for instance, describes how 'the Scotch the English faire entreate' (C2r), and Rumour elides England with Britain, declaring 'Britaines when they fight with cheere, they say / God and Saint George for England to this day' (C1v). ${ }^{64}$ In this context, Britishness is a mode of English identity that incorporates marginal elements in order to 
retain their subordinateness. Cambria's speech calls Henry 'Great Britaines matchlesse Heire' and the 'Prop of Englands joy' (C1r). The character of Peace only briefly mentions Scottish place within the union, whereas Welsh identity is given more extensive representation in the form of personification (as Cambria). As Barrett notes, 'the British nation in the show is effectively a fusion of English and Welsh peoples'. ${ }^{65}$ This view of British identity gives the city of Chester a centralized role as a fulcrum between its two dominant elements, and as a characteristic element of the combined whole. Such representativeness extends reflexively throughout the entertainment's symbolism. The representatives of Chester stand in for a figure (Brut) who symbolizes the unified nation which the king's body signifies in turn; but visual and aural symbols stand in for the king's body in its own absence, as noted above. Virtually everything present at this event symbolizes something else, in an economy of representation that is clearly directed towards flattering the authorities of an English-identified city undergoing a broad economic and political decline. ${ }^{66}$

The view Chester presented of itself to its audiences in 1610 maintains the bygone prestige of a medieval power centre. Chesters Triumph reimagines ways in which the city can be both distinctive and representative, separate to and incorporated within wider national identities. Within the text of the triumph, different elements of its audiences come to stand in for Chester at different points, including the show's proposer, Robert Amery. The printed account of the event makes several gestures aggrandizing his role, including a postscript whose wording implies that Amery 'authored' the entire 'pleasing show' (as well as the postscript itself):

IF any Reader shall desire to know

Who was the Author of this pleasing show:

Let him receave advertizement hereby

A Sheriffe (late of Chester) AMERIE.

Did thus performe it; who for his reward,

Desires but Love, and competent regard.
ROBERT AMERIE
$(\mathrm{D} 1 \mathrm{v}-\mathrm{D} 2 \mathrm{r})$

The postscript presents Amery as both author and performer, both the animating spirit behind the event, and the individual who perfected and created its enactment, simultaneously speaking for and to the city. Richard Davies's introductory address to the reader expands his role, which emphatically gives Amery the credit for the entire enterprise when he states that the event 
shall remaine and continue perpetually to future ages, as a memorable and worthy project, founded, devised, and erected onely by the most famous, generous, and well deserving Citizen, Mr. ROBERT AMERIE, late Sherieffe of the said Citie. (A3r)

Amery's claims recruit yet another kind of representativeness, whereby a citizen of Chester can present himself as a genius loci, and in doing so, appeal to a variety of local constituencies in his efforts to gain support for the show and the ongoing annual races.

Chesters Triumph presents a range of levels and kinds of representativeness. The body of an individual actor, the people who watch the show, the officials dressed in the robes of office, metaphorical associations, and the sound and image of music all personify the city. In turn, the pageant invokes the city as portraying a particular vision of the hybridity of the seventeenth-century nation. These claims of representation are, however, just claims. The overlapping circuits of association that the event invokes remain open to interpretation. As Barrett notes, 'the show leaves spectators to their own devices when choosing who will occupy the prince's place'. ${ }^{67}$ The show oscillates between singularity and universality, differentiation and homogenization. It asserts the right of various individuals and symbols to stand in for larger entities and abstract identities, but does not come to a singular resting point of meaning. Like all early modern pageantry, Chesters Triumph has to speak to a disparate audience to sometimes contradictory purposes, and it achieves this polysemy through the open-endedness of its signification, presenting enigmatic visual and aural symbols that can carry multiple meanings for a range of spectators and readers.

\section{Notes}

I wish to thank David Lindley, Bonnie Latimer, and the members of the Leeds Early Career Researchers Group for feedback on this article in its early stages.

1 For a thorough account of the political context of Henry's investiture see Pauline Croft, 'The Parliamentary Installation of Henry, Prince of Wales', Historical Research 65 (1992), 177-93. DOI: http://dx.doi.org/10.1111/j.1468-2281.1992.tb00927.x.

2 See David Bergeron's several works including English Civic Pageantry, 1558-1642 (London, 1971; revised edn 2003); 'Medieval Drama and Tudor-Stuart Civic Pageantry', The Journal of Medieval and Renaissance Studies 2 (1972), 279-93; 'Stuart 
Civic Pageants and Textual Performance', Renaissance Quarterly 51.1 (1998), 16383, DOI: http://dx.doi.org/10.2307/2901666; Textual Patronage in English Drama, 1570-1640 (Aldershot, 2006); 'Creating Entertainments for Prince Henry's Creation (1610)', Comparative Drama 42.4 (2008), 433-49, DOI: http://dx.doi. org/10.1353/cdr.0.0033. On pageantry more generally, see 'King James' Civic Pageant and Parliamentary Speech in March 1604', Albion 34.2 (2002), 213-31, DOI: http://dx.doi.org/10.2307/4053700; 'The "I" of the Beholder: Thomas Churchyard and the 1578 Norwich Pageant', Jayne Elizabeth Archer, Elizabeth Goldring and Sarah Knight (eds), The Progresses, Pageants, and Entertainments of Elizabeth I (Oxford, 2007), 142-59; and 'Charismatic Audience: A 1559 Pageant', Nova Myhill and Jennifer A. Low (eds), Imagining the Audience in Early Modern Drama, 1558-1642 (Basingstoke, 2011), 135-49.

3 Bergeron, 'Creating Entertainments', 437.

4 Robert W. Barrett, Against All England: Regional Identity and Cheshire Writing, 1195-1656 (Notre Dame, 2009).

5 David Mills, Recycling the Cycle: The City of Chester and its Whitsun Plays (Toronto, 1998), 138.

6 This omission is somewhat surprising for a critic who has done much work on the musical resources of early modern Chester. See 'Music in the City', in Elizabeth Baldwin, Paying the Piper: Music in Pre-1642 Cheshire (Kalamazoo, 2002), 54-78.

7 Peter Walls's book on the court masque remains the only study which offers a sustained consideration of the musical elements of this kind of early modern occasional performance. See Peter Walls, Music in the English Courtly Masque (Oxford, 1996). Mary Chan's book, Music in the Theatre of Ben Jonson (Oxford, 1980), appears to offer an account of the importance of music within Jonson's plays and masques, but despite her inclusion of many musical examples, the text is really a discussion of Jonson's philosophy and artistic development.

8 See Bruce R. Smith, The Acoustic World of Early Modern England: Attending to the $O$-Factor (Chicago, 1999) for an examination of aural culture in the period. The authoritative account of music in early modern culture is Christopher Marsh, Music and Society in Early Modern England (Cambridge, 2010).

9 The fullest musical evidence survives in relation to the court masque. See, for example, Andrew Sabol (ed.), Four Hundred Songs and Dances from the Stuart Masque (Providence, 1978).

10 As Mary Chan has observed, amateurs or teachers primarily used notated music, particularly in print, not the professional musicians who were engaged to perform at civic entertainments. See Chan, 'Music Books', John Barnard and D.F. McKenzie (eds), The Cambridge History of the Book in Britain (Cambridge, 2002), 131. 
DOI: http://dx.doi.org/10.1017/CHOL9780521661829.007. See David Fuller, 'The Performer as Composer', Howard Mayer Brown and Stanley Sadie (eds), Performance Practice: Music after 1600 (London, 1989), 117-46 and Robert Donington The Interpretation of Early Music, rev. edn (London, 1989). Caccini's comment in his 1614 Nuove musiche e nuova maniera di scriverle that one can now use notation to learn music 'without having to hear the composer sing' shows just how novel certain kinds of written music still were. Cited in Jette Barnholdt Hansen, 'From Invention to Interpretation: The Prologues of the First Court Operas Where Oral and Written Cultures Meet', Journal of Musicology 20 (2003), 559 (Hansen's translation). DOI: http://dx.doi.org/10.1525/jm.2003.20.4.556.

11 The document is reproduced in REED: Cheshire Including Chester, Elizabeth Baldwin, Lawrence M. Clopper and David Mills (eds) 2 vols (Toronto, 2007), 1.351-3. See Barrett for a discussion of Amery's efforts to enlist financial support for this venture (116-18).

12 The print version gives the name of the writer as Richard Davies, who appears to have been a local poet. See Barrett for a discussion of the possibility that Prince Henry received a presentation copy of this document (112).

13 As Muriel C. McClendon notes, St George was particularly associated with military organizations and endeavours. See 'A Moveable Feast: Saint George's Day Celebrations and Religious Change in Early Modern England', Journal of British Studies 38.1 (January 1999), 1-27.

14 Such militaristic ambitions are further encouraged by the rather belligerent speech that Cambria gives in Henry's honour, though this encouragement is balanced out by Peace's prominence and a speech honouring King James and his pacifism (see below). On the hopes surrounding Prince Henry's future, see J.W. Williamson, The Myth of the Conqueror: Prince Henry Stuart, A Study of Seventeenth Century Personation (New York, 1978); Frances Yates, Shakespeare's Last Plays: A New Approach (London, 1975), 17-37; Graham Parry, The Golden Age Restor'd: The Culture of the Stuart Court (Manchester, 1981), 83-4; Roy Strong, Henry, Prince of Wales, and England's Lost Renaissance (London, 1986); David M. Bergeron, Royal Family, Royal Lovers: King James of England and Scotland (London, 1991), 92-109.

15 Chesters Triumph in Honor of Her Prince (London, 1610) A4r-v. Further references to this text are given as sigla after quotations in the text. Abbreviations have been silently expanded, and $\mathrm{i}$ and $\mathrm{u}$ have been transcribed as $\mathrm{j}$ and $\mathrm{v}$ respectively where appropriate.

16 REED Cheshire, 1.351.

17 JoAnna Dutka, Music in the English Mystery Plays, Early Drama, Art, and Music Monograph Series 2 (Kalamazoo, 1980), 6. Adrian Rose argues that music itself is 
symbolic of the heavenly in the mystery plays. See 'Angel Musicians in the Medieval Stained Glass of Norfolk Churches', Early Music 29.2 (2001), 191.

18 Furthermore, the appearance of a personation of Mercury would surely have been rather different to the appearance of a personation of God or angels.

19 Campion describes one of the songs in Lord Hay's Masque as 'a sollemne motet of sixe parts'. See Walter R. Davis, ed., The Works of Thomas Campion (London, 1969), 224.

20 The maximum number of parts in Pilkington's surviving madrigals is six.

21 According to Jerome Roche, most English madrigals were written in an intensive craze between 1588-1608. See The Madrigal (London, 1972), 125.

22 For a detailed account of the involvement of different groups of musicians in the musical life of the city in general, see Mills, 'Music in the City', in Baldwin, Paying the Piper, 62-75.

23 For example, the Cordwainers and Shoemakers recorded that they had paid the Waits 2 s and 'the kellyes' $2 \mathrm{~s} 6 \mathrm{~d}$ 'at shroftyde' in 1610, presumably for music at the Shrovetide races (see REED Cheshire, 1.356).

24 George Kelly was made a freeman of the city without having to pay any charge in 1608 (REED Cheshire, 1.314).

25 REED Cheshire, 1.383, 2.606, and 1.401.

26 REED Cheshire, 1.407-8.

27 REED Cheshire, 1.393.

28 See Marsh, 94-5. See also A.L. Beier, Masterless Men: The Vagrancy Problem in England, 1560-1640 (London, 1985), 96-9 and Walter L. Woodfill, Musicians in English Society from Elizabeth to Charles I (Princeton, 1953), 118-19.

29 Baldwin, Paying the Piper, 10.

30 In 1600, the brothers resorted to a third party judgment to resolve the dividing up of profits between themselves and their apprentices (REED Cheshire, 1.268). See also Mills, 'Music in the City', 74.

31 REED Cheshire, 1.352.

32 Mary Remnant, Musical Instruments of the West (London, 1978), 139, 150. Manifold considers that cornetts distinguished 'dignitaries of lesser rank than king' in the theatre. See J.S. Manifold, The Music in English Drama from Shakespeare to Purcell (London, 1956), 53, although Galpin notes that cornetts were used to announce the entry of kings in some plays, for example Gorbudoc. Francis W. Galpin, Old English Instruments of Music: Their History and Character, rev. by Thurston Dart (London, 1965), 140-4.

33 Barrett, Against All England, 102.

34 Book 7, chapter 6 of $A b$ Urbe Condita recounts the legend as an alternative etymology for the Lacus Curtius. 
35 According to $O E D$, the usage of this word to mean haemorrhoid dates from the early fifteenth century.

36 Envie's invocation of plague seems an insensitive jibe to make in a town that had lost perhaps a third of its population in an outbreak only five years previously. Thanks to Dominic Williams for alerting me to this connection.

37 Barrett, Against All England, 105-10.

38 REED: Cheshire, 1.350-1. A note appended to this petition (see 1.351) seems to imply that it was unsuccessful, but the mayor's petition of 20 July 1610 to the Company of Cooks, Innholders, and Victuallers requesting contributions to compensate Amery for the charges incurred suggests that Amery's suit did eventually have some limited success (REED: Cheshire, 1.358-9). Barrett estimates that Amery can only have ever received a tiny fraction of the $£ 100$ he claims to have paid out (Barrett, Against All England,118).

39 Andrew Gurr, Playgoing in Shakespeare's London, 3rd edition (Cambridge, 2004), 59.

40 Alfred Harbage, Shakespeare's Audience (New York, 1961), 76.

41 Ibid, 55.

42 Cook and Harbage gather similar evidence about the London population, though they use it to come to opposing conclusions about the composition of theatre audiences. See Harbage and Anne Jennalie Cook, The Privileged Playgoers of Shakespeare's London, 1576-1642 (Princeton, 1981).

43 Jeremy Lopez, Theatrical Convention and Audience Response in Early Modern Drama (Cambridge, 2003), 16. DOI: http://dx.doi.org/10.1017/CBO9780511483714. Charles Whitney offers a useful perspective, in his chapter on 'common understanders', where he characterizes the heterogeneity of these audience members as a 'positive resource'. Instead of something to be smoothed over by transcendental dramatic gestures, it is something that skilful performers could enjoy and engage with. See Charles Whitney, Early Responses to Renaissance Drama (Cambridge, 2006), 198.

44 Barrett, Against All England, 110-19

45 G.C.F. Forster, N.J. Alldridge and A.P.M. Wright, 'Early Modern Chester, 15501762', C.P. Lewis and A.T. Thacker (eds), VCH: Chester, vol. 5, part 1 (Oxford, 2003), 91-8.

46 Donald Woodward, Men at Work: Labourers and Building Craftsmen in the Towns of Northern England, 1450-1750 (Cambridge, 1995), 198. DOI: http://dx.doi. org/10.1017/CBO9780511522871.

47 A.D.M. Phillips and C.B. Phillips, A New Historical Atlas of Cheshire (Chester, 2002), 42.

48 Mills, 'Music in the City', 54. See also Donald Woodward, 'The Port of Chester in Context', Peter Carrington (ed.), Where Deva Spreads Her Wizard Stream: Trade and 
the Port of Chester, Chester Archaeology Occasional Papers No. 3 (Chester, 1996), 61-5.

49 The midsummer watch had been instituted in c.1499 (see Lawrence M. Clopper REED: Chester [Toronto, 1979], xliii and lii on the question of dating). Some kind of sporting event had been held at Shrovetide for several years before regulations were drawn up in 1539. The REED: Cheshire editors point out that contemporary antiquarian David Rogers notes the large crowds drawn to the town for the Whitsun mystery plays (REED: Cheshire, 1.xxxvi).

50 See C.P. Lewis, 'Chester Races' in Lewis and Thacker, A History of the County of Chester, vol. 5 part 2, 255-60, and R.M. Bevan, The Roodee: 450 Years of Racing in Chester (Northwich, 1989).

51 REED Cheshire, 1.352. Such socially-differentiated hospitality was standard practice in the London lord mayors' shows, where the new lord mayor and members of the livery companies were feasted in the Guildhall.

52 Stephen Orgel, 'The Spectacles of State', reprinted in Stephen Orgel, The Authentic Shakespeare, and Other Problems of the Early Modern Stage (London, 2002), 83.

53 Though some commentators have assumed that Prince Henry was present. See, for example, Joan Beck, Tudor Cheshire, A History of Cheshire, vol. 7 (Chester, 1969), 62.

54 Barrett, Against All England, 105.

55 Martin Butler, The Stuart Court Masque and Political Culture (Cambridge, 2008), 4.

56 Thomas Middleton, The Triumphs of Honor and Industry (1617), ed. Bergeron and Kate D. Levin (annotations and introduction), in Gary Taylor and John Lavagnino (gen. eds), Thomas Middleton, The Collected Works, (Oxford, 2007), 1253-63.

57 As I argue in 'Representations of India on Jacobean Popular Stages', Theatre Survey 54.1 (2013), 20. DOI: http://dx.doi.org/10.1017/S0040557412000397.

58 Although earlier neoplatonic paradigms of musical affect were being superseded in the seventeenth century, these ideas still retained a residual poetic power. Marsh comprehensively covers the scientific and mythological bases for the contemporary understanding of music's power in chapter 2 of his book (32-70). See also Penelope Gouk, 'The Role of Harmonics in the Scientific Revolution', Thomas Christensen (ed.) The Cambridge History of Western Music Theory (Cambridge, 2002), 223-45, DOI: http://dx.doi.org/10.1017/CHOL9780521623711.010 and John Hollander, The Untuning of the Sky: Ideas of Music in English Poetry, 1500-1700 (New York, 1970), 333.

59 In some cases, the noise of the crowds delayed proceedings, as in Millington's account of James's 1603 visit to Berwick en route from Edinburgh to London. The noise of the crowds was such that it prevented the town's recorder making his 
intended address to the king. Only when the noisy onlookers 'were (in a manner) intreated to be silent' and ceased their shouting of 'Welcome' and 'God save King James' could the speech go ahead. See John Nichols (ed.), The Progresses, Processions, and Magnificent Festivities of King James the First, 4 vols (London, 1828), 1.64.

60 Gretchen Ludke Finney, Musical Backgrounds for English Literature, 1580-1650 (New Jersey, 1962; rpt. Connecticut, 1976), 29-30. This trope recurs throughout early modern poetic invocations of music. See Elise Bickford Jorgens, The WellTun'd Word: Musical Interpretations of English Poetry 1597-1651 (Minneapolis, 1982); Hollander, The Untuning of the Sky; James Anderson Winn, Unsuspected Eloquence: A History of the Relations between Poetry and Music (New Haven, 1981).

61 Barrett, Against All England, 122.

62 James's Basilicon Doron had referred to this version of the origins of Britain, and writers such as Anthony Munday drew on it. See Bergeron, Pageants and Entertainments of Anthony Munday: A Critical Edition (New York, 1985), xiii.

63 According to Pauline Croft the 1607 parliament comprehensively destroyed the union scheme. See King James (Basingstoke, 2003), 65-6. Brian P. Levack considers that, despite rhetorical assertions to the contrary, James himself had abandoned hope of a union of laws as well as crowns by this stage. See The Formation of the British State: England, Scotland and the Union, 1603-1707 (Oxford, 1987), 180, n 30.

64 The echo of Henry $V$ here brings in another Prince Henry strongly associated with Wales, suggesting that the addition of Scotland makes little difference to the nature of Britishness from the point of view of the Welsh border. John Kerrigan discusses the Welsh perspective on union in 'The Romans in Britain, 1603-1614', Glenn Burgess, Rowland Wymer, and Jason Lawrence (eds), The Accession of James I: Historical and Cultural Consequences (Basingstoke, 2006), 113-39.

65 Barrett, Against All England, 127.

66 Chester's economic decline was caused largely by the silting of the river Dee. Despite attempts to remedy the situation, the large port revenues of the fifteenth century were never to be regained. See Simon Ward, Chester: A History (Chichester, 2009), 56. This recession coincided with the undermining of the city's administrative autonomy across the Tudor period. See Tim Thornton, Cheshire and the Tudor State: 1480-1560 (Woodbridge, 2000).

67 Barrett, Against All England, 103. 
